\title{
Accumulation of nerve growth factor and its receptors in the uterus and dorsal root ganglia in a mouse model of adenomyosis
}

\author{
Yan Li ${ }^{1,2}$, Shao-fen Zhang ${ }^{1 *}$, Shi-en Zou', Xian Xia', Lei Bao ${ }^{1}$
}

\begin{abstract}
Background: Adenomyosis is a common gynecological disease, which is accompanied by a series of immunological and neuroendocrinological changes. Nerve growth factor (NGF) plays a critical role in producing pain, neural plasticity, immunocyte aggregation and release of inflammatory factors. This study aimed to investigate the expression of NGF and its two receptors in uteri and dorsal root ganglia (DRG) in an adenomyosis mouse model, as well as their relationship with the severity of adenomyosis.
\end{abstract}

Methods: Forty newborn ICR mice were randomly divided into the adenomyosis model group and control group ( $n=20$ in each group). Mice in the adenomyosis model group were orally dosed with $2.7 \mu \mathrm{mol} / \mathrm{kg}$ tamoxifen on days 2-5 after birth. Experiments were conducted to identify the expression of NGF- beta and its receptors, tyrosine kinase receptor (trkA) and p75 neurotrophin receptor (p75NTR), in the uterus and DRG in four age groups (90+/-5 $d, 140+/-5 \mathrm{~d}, 190+/-5 \mathrm{~d}$ and $240+/-5 \mathrm{~d} ; \mathrm{n}=5$ mice in each group) by western bolt, immunochemistry and real time reverse transcription-polymerase chain reaction.

Results: Adenomyosis, which became more serious as age increased, was successfully induced in dosed ICR mice. NGF-beta, trkA and p75NTR protein levels in the uterus and trkA mRNA levels in DRG were higher in the older aged adenomyosis model group than those in controls (190+/-5 $d$ and $240+/-5 d$ groups, $P<0.05$ ). The expression of NGF-beta and its receptors in the uterus increased gradually as age increased for adenomyosis mice (190+/-5 $\mathrm{d}$ and 240+/-5 d, $P<0.05$, compared with 90+/-5 d) but it showed little change in control mice. The mRNA level of trkA in DRG also increased as age increased in the adenomyosis model group (190+/-5 d and 240+/-5 $d, P<0.05$, compared with $90+/-5$ d) but was unchanged in controls. The mRNA level of p75NTR in DRG was not different between the adenomyosis and control groups and was stable from young to old mice.

Conclusions: NGF- beta can be used as an indicator for the severity of adenomyosis. The gradually increasing level of NGF- beta and its receptors while the disease becomes more severe suggests an effect of NGF- beta on pathogenic mechanisms of adenomyosis.

\section{Background}

Adenomyosis is defined as the presence of ectopic endometrial glands and stroma within the myometrium. It is a relatively frequent endomyometrial pathology that is found in multiparous women between 40 and 50 years of age [1]. Approximately $2 / 3$ of women with adenomyosis are symptomatic with menorrhagia and dysmenorrhoea [2]. However, the etiology and pathogenic

\footnotetext{
* Correspondence: zhangshaofen@163.com

'Department of Gynaecology, Obstetrics and Gynaecology Hospital, Fudan University, Shanghai, 200011, PR China

Full list of author information is available at the end of the article
}

mechanisms responsible for adenomyosis are poorly understood.

An impaired neuroimmune status may be necessary for the maintenance of adenomyosis, and it could play an important part in the mechanism by which the symptoms of adenomyosis are generated [3-5]. NGF was the first neurotrophic factor to be discovered and it plays a critical role in producing pain, neural plasticity, immunocyte aggregation, and release of inflammatory factors [6,7]. Several studies have suggested that abnormal expression of NGF in adenomyosis and endometriosis might be involved in the pathomechanism of these

\section{C) Biomed Central}


diseases [8-10]. Studies in humans and rat have shown that there is an intense NGF- $\beta$ immunoreactivity near ectopic endometriotic glands [10-12]. The receptors of NGF are high-affinity tyrosine kinase receptor (trkA) and low-affinity p75 neurotrophin receptor (p75NTR), and they are immunoreactive in nerve fibers that are close to endometriotic glands and blood vessels [13-15]. A potential involvement of NGF- $\beta$ in innervation and pain occurring in endometriosis has been suggested [9]. In our previous studies, we found a higher NGF- $\beta$ expression in adenomyosis mice, which might explain the augmented innervation and inflammation status in the uterus [8]. Abnormal expression of the nonfunctional subunit NGF- $\alpha$ (not the functional subunit NGF$\beta$ ) has also been detected in uteri of newborn mice, which acquire adenomyosis in adulthood $[16,17]$.

Discovered over 50 years ago, NGF has been extensively studied in various biological systems in an attempt to understand its role in adenomyosis. It has been shown to play significant roles in the transmission of physiological and pathological pain [6,7]. Transgenic animals lacking the gene for NGF and trkA are hypoalgesic and are born without small diameter nociceptive sensory neurons $[18,19]$. In contrast, animals that over express NGF, or humans injected with NGF in cutaneous targets, have behavioral or sensorius hyperalgesia $[20,21]$. The mechanism of how NGF is involved in pain is manifold and complicated. NGF can promote the proliferation of nerve fibers and improve their sensitivity. NGF is crucial for the development of sympathetic and small fiber sensory neurons that serve as nociceptors [6]. It is also involved in sensitizing or exciting the terminals of sensory nerve fibers by stimulating the expression and release of neuropeptides [22]. NGF plays an important role in mediating and/or regulating the immune response. It has been proposed that NGF is involved in the recruitment, survival, and activation of mast cells, $\mathrm{T}$ cells of the Th2 phenotype, and eosinophil infiltration [23]. By stimulating the degranulation of mast cells, NGF can promote the release of inflammatory mediators such as serotonin [24]. In addition, NGF affects non-neurocyte proliferation, such as in myogenous cells [25], cystic smooth muscle cells [26] and corneal epithelial cells [27]. NGF might also participate in stress-triggered and substance P-mediated abortion [28].

Adenomyosis is associated with recurrent and aggressive pain syndrome, impaired immune status, and also characterized by intensified weighted uterus and a high rate of spontaneous abortion [2-4,29]. Since NGF has abnormal expression in adenomyosis and has multiple effects on innervation, immunoregulation, cell proliferation and production of pain, it might be involved in the pathomechanism of adenomyosis. If NGF plays a role in adenomyosis, NGF levels and/or its receptors might change with the progress of this disease. To determine this possibility, we administered tamoxifen in an adenomyosis mouse model. This model has an aggravated pathogenetic condition of adenomyosis as age increases. In addition, it is not associated with trauma and has relatively normal sex hormone levels, which are important for considerations because trauma and sex hormone affect the expression of NGF $[6,7,30]$.

In this study, we examined the relationship between NGF- $\beta$ and the severity of adenomyosis. By examining the protein and mRNA levels of NGF and its receptors in the uterus and dorsal root ganglia (DRG) at different ages in adenomyosis mice, we aimed to evaluate any changes with the severity of adenomyosis in peripheral organs and the central nerve system.

\section{Methods}

\section{Animals and treatments}

Neonatal healthy female ICR mice (SCXK 2007-0005, SLAC laboratory animal CO. LTD, Shanghai, China) were housed in negative pressure isolators with a controlled temperature $\left(23-25^{\circ} \mathrm{C}\right)$ and $12 \mathrm{~h}$ alternating light ( 8 a.m to 8 p.m) and dark cycle. To induce the adenomyosis mouse model, neonatal mice were orally dosed daily on days 2 to 5 after birth (day of birth was day 1) with $2.7 \mu \mathrm{mol} / \mathrm{kg}$ tamoxifen (Fudan Forward Co., Shanghai, China) suspended in a peanut oil/lecithin/condensed milk mixture (2:0.2:3, by volume) at a dose volume of $5 \mu \mathrm{l} / \mathrm{g}$ body weight. Controls received no treatment. The 4 day estrous cycle was determined by the presence of a characteristic vaginal discharge in the morning. ICR Mice with at least 1 consecutive 4-day estrous cycle were used in the present study. All experimental procedures were approved by the Ethics Committee of Obstetrics and Gynecology Hospital, Fudan University.

\section{Euthanasia and processing of tissue}

All mice were sacrificed at 5 p.m. by injecting propofol $(10 \mathrm{mg} / \mathrm{kg}$ injection, i.v.) on proestrus at age $90 \pm 5,140$ $\pm 5,190 \pm 5$ and $240 \pm 5 \mathrm{~d}(\mathrm{n}=5$ in each group). T13 to L2 DRG were harvested and stored in liquid nitrogen. Bilateral uteri were removed. After weighing, the uteri were either frozen in liquid nitrogen or fixed in $4 \%$ neutral paraformaldehyde at $4^{\circ} \mathrm{C}$.

\section{Immunohistochemistry and immunofluorescence}

Formalin-fixed, $5 \mu \mathrm{m}$ paraffin sections of mouse uterus were dewaxed and taken to water by immersing in xylene and gradient ethanol. Hematoxylin and eosin (HE) staining was performed first to determine whether there were adenomyosis nodes. Sections were then immersed in boiling citrate buffer ( $\mathrm{pH} \mathrm{6.0)}$ for $20 \mathrm{~min}$. Endogenous peroxidase activity was blocked with $3 \%$ $\mathrm{H} 2 \mathrm{O} 2$ for $30 \mathrm{~min}$ and then goat serum for $15 \mathrm{~min}$. 
Sections were then incubated with specific polyclonal rabbit antibodies for NGF (Santa Cruz Biotechnology, Santa Cruz, CA, USA) at a dilution of 1:500, p75NTR (Epitomics, Burlingame, CA, USA) at a dilution of 1:100, or trkA (Epitomics, Burlingame, California, USA) at a dilution of $1: 100$, at $4^{\circ} \mathrm{C}$ overnight. The next day, sections were incubated with biotinylated goat anti-rabbit IgG (Zhongshan Golden Bridge Biotechnology Co., Ltd, Beijing, China) for $15 \mathrm{~min}$ and then streptavidin-peroxidase complex (Zhongshan Golden Bridge Biotechnology Co., Ltd) for another $15 \mathrm{~min}$ at room temperature. Staining was visualized with 3,3'-diaminobenzidine for $3 \mathrm{~min}$ at room temperature (Zhongshan Golden Bridge Biotechnology Co., Ltd) and hematoxylin counter stain. After incubated with trkA (1:100) at $4^{\circ} \mathrm{C}$ overnight, some sections were incubated with biotinylated goat anti-rabbit IgG (Boster, Wuhan, Hubei, China) for $30 \mathrm{~min}$ at $37^{\circ} \mathrm{C}$ and then streptavidin- fluorescein isothiocyanate complex (Boster, Wuhan, Hubei, China) for another $30 \mathrm{~min}$ at $37^{\circ} \mathrm{C}$. Negative controls included omission of the primary or secondary antibody. There was no labeling in different groups and any of the control sections. Paraffin sections of mouse brain were used for positive control following the instruction for the antibody of NGF, p75NTR and trkA. Slides were examined using a radiophoto microscope (BX51, Olympus, JP) equipped with a digital camera (DP71, Olympus, JP).

\section{Western blot analysis}

The uteri of adenomyosis and control mice were homogenized and lysed in ice cold RIPA lysis buffer (consisting of $50 \mathrm{mM}$ Tris [pH 7.4], $150 \mathrm{mM} \mathrm{NaCl}, 1 \%$ NP- $40,0.5 \%$ sodium deoxycholate, $0.1 \%$ SDS and protease inhibitors; Beyotime, Haimen, Jiangsu, China) with $1 \mathrm{mM}$ phenylmethylsulfonyl fluoride. Each sample containing $40 \mu \mathrm{g}$ protein was separated by $12 \%$ SDSPAGE. Protein bands of samples were then electrically transferred on PVDF membranes (Millipore, Billerica, MA, USA) at $300 \mathrm{~mA}$ for $2 \mathrm{~h}$. After blocking with $10 \%$ defatted milk, membranes were incubated with rabbit multiclonal anti-mouse NGF (Santa Cruz) at a dilution of 1:500, monoclonal anti-mouse trkA (Epitomics) at a dilution of 1:1000, monoclonal anti-mouse p75NTR (Epitomics) at a dilution of 1:5000, or monoclonal anti-mouse beta-actin (Sigma, St. Louis, MI, USA) at a 1:1000 dilution at $4^{\circ} \mathrm{C}$ overnight. Membranes were then incubated with peroxidase-labeled secondary antibody (Jackson, West Grove, PA, USA) at a dilution of 1:5000 for $1 \mathrm{~h}$. The chemiluminescent signal was developed using BeyoECL Plus (Beyotime, Haimen, Jiangsu, China) for 2 min and quantitated over a 5-10 min exposure using a Chemiluminescent and Fluorescent Imaging System (Fluochem FC2, Alpha Innotech, San Leandro, CA, USA).
Real time reverse transcription polymerase chain reaction (real time RT-PCR)

Total RNA from DRG (T13 to L2 together) was isolated using TRIzol reagent (Invitrogen, Carlsbad, CA, USA). Complementary DNA was synthesized from $1 \mu \mathrm{g}$ RNA using superscript II reverse transcriptase and oligo (dT) 12-18 primers (Fermentas, Glen Burnie, MD, USA). Real-time PCR reactions were performed using a BioRad IQ5 machine (Bio-Rad, Hercules, CA, USA) and SYBR Premix Ex TaqTM II (Takara, Dalian, Liaoning, China) according to the manufacturer's instructions. Each $20 \mu \mathrm{l}$ reaction buffer contained $10 \mu \mathrm{l}$ of $2 \times$ SYBR Premix Ex TaqTM II, $0.8 \mu \mathrm{l}$ of primers at $10 \mu \mathrm{M}, 2 \mu \mathrm{l}$ of diluted cDNA template, and $6.4 \mu \mathrm{l}$ of ddH2O. The PCR conditions were $95^{\circ} \mathrm{C}$ for $5 \mathrm{sec}$ and $60^{\circ} \mathrm{C}$ for $30 \mathrm{sec}$, for 40 cycles. The primers for Actb (gene for beta-actin) were: forward, 5'-CCT CTA TGC CAA CAC AGT GC3' and reverse, 5'-GTA CTC CTG CTT GCT GAT CC3'; Ntrk1 (gene for trkA): forward, 5'-ATA TCT AGC CAG CCT GCA CTT TGT-3' and reverse, 5'-TGC TCA TGC CAA AGT CTC CA-3'; and Ngfr (gene for p75NTR): forward, 5'-TAT AGA CTC CTT TAC CCA CG-3' and reverse, 5'-AAT GTC AGC TCT CTG GAT G-3'. The relative mRNA levels of Ntrk1 and Ngfr were calculated and normalized against the level of Actb.

\section{Statistics}

All data were analyzed by SAS 6.12 (SAS institute Inc, Cary, NC, USA) and expressed as mean \pm SD. The results of wesrern blot and gene expression were subjected to one-way ANOVA. The results of uterine and body weight were subjected to t-tests to compare the mean value. A value of $\mathrm{P}<0.05$ was considered to be statistically significant.

\section{Results}

\section{Adenomyosis model of ICR mice}

All mice dosed with tamoxifen developed adenomyosis in this study. None of the controls had adenomyosis nodes in the uteri (Figure 1A). The depth and area of ectopic endometrium were increased as age increased for tamoxifen dosed mice (Figure 1B-E). Nodules of endometrial glands and stroma were present deep within the myometrium, sometimes extending to, but not penetrating, the serosa. Unilateral uterine weight and body weight for both dosing mice and controls is shown in Table 1. For tamoxifen dosed mice, at first, their uteri were lighter $(90 \pm 5 \mathrm{~d}$, $\mathrm{P}<0.05)$ and then they became heavier $(190 \pm 5 \mathrm{~d}, 240 \pm$ $5 \mathrm{~d} ; \mathrm{P}<0.05)$ than those in controls.

\section{Immunochemical localization of NGF- $\beta$, trkA and p75NTR in the uterus}

We performed immunohistochemical and immunofluorescence analysis to analyze the temporal and spatial 

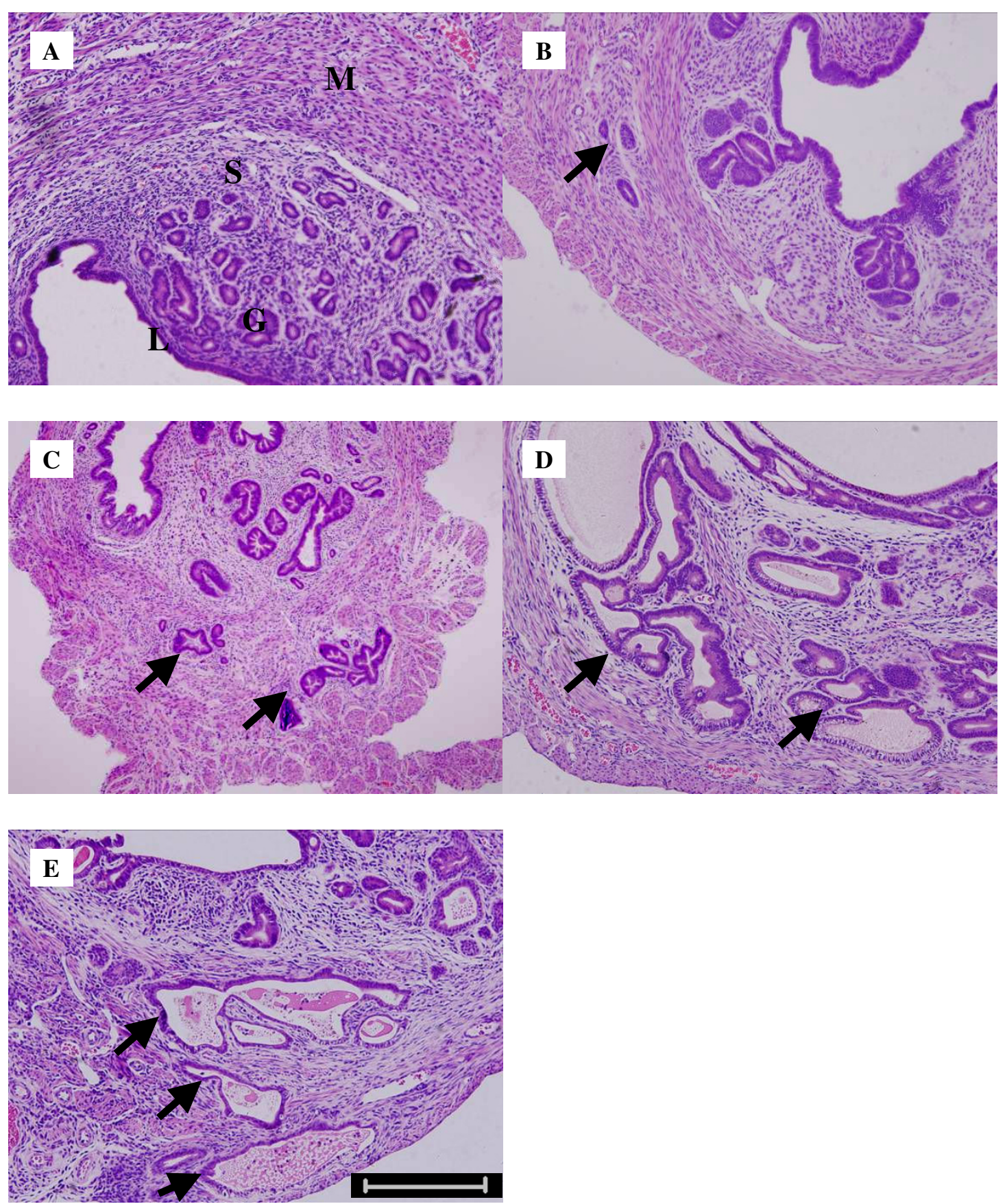

Figure $1 \mathrm{HE}$ staining of paraffin-embedded sections. A: Uterus of $140 \pm 5 \mathrm{~d}$ ICR mice as control. B:Uterus of $90 \pm 5 \mathrm{~d}$ ICR mice with biopsy confirmed adenomyosis; C: Uterus of $140 \pm 5$ d ICR mice with biopsy confirmed adenomyosis; D: Uterus of $190 \pm 5$ d ICR mice with biopsy confirmed adenomyosis; E: Uterus of $240 \pm 5$ d ICR mice with biopsy confirmed adenomyosis; (L, luminal epithelium; G, glandular epithelium; S, stromal cell; M, myometrium cell; arrows, ectopic endometrium; Bar = 50 $\mu \mathrm{m})$.

changes in the expression of NGF- $\beta$, trkA and p75NTR in the uterus. In the uteri of both adenomyosis and control mice, NGF- $\beta$ immunoreactivity was predominantly observed in the luminal epithelial cells, glandular cells, and stromal cells of the endometrium. NGF- $\beta$ immunohistochemical positive signals were scarce in myometrial cells
(Figure 2A-E). Immunoreactivity of p75NTR was detected mainly in endometrial stromal cells (Figure 2F-J). Immunoreactivity of trkA was detected in nerve fibers distributed in the uterus (Figure $2 \mathrm{~K}$ ). Additionally, trkA was also weakly expressed in luminal epithelial cells and glandular cells in the endometrium (Figure 2L). The ectopic 
Table 1 The unilateral uterine weight and body weigh of adnomyosis and control ICR mice

\begin{tabular}{lccc}
\hline Group & Age (d) & Uterine weight $(\mathbf{m g})$ & Body weight (g) \\
\hline Control & $90 \pm 5$ & $227.6 \pm 23.5$ & $43.80 \pm 2.35$ \\
& $140 \pm 5$ & $227.8 \pm 17.2$ & $43.32 \pm 2.62$ \\
& $190 \pm 5$ & $215 \pm 9.76$ & $45.98 \pm 2.92$ \\
Adenomyosis & $240 \pm 5$ & $223.8 \pm 24.2$ & $44.17 \pm 3.12$ \\
& $90 \pm 5$ & $174.8 \pm 14.8^{*}$ & $42.78 \pm 2.49$ \\
& $140 \pm 5$ & $206.0 \pm 21.0$ & $47.84 \pm 3.21$ \\
& $190 \pm 5$ & $243.3 \pm 21.6^{*}$ & $49.68 \pm 3.50$ \\
& $240 \pm 5$ & $243.0 \pm 27.0^{*}$ & $45.84 \pm 5.11$ \\
\hline
\end{tabular}

$\mathrm{MEAN} \pm \mathrm{SD} ; \mathrm{n}=5 ;{ }^{*} \mathrm{P}<0.05$ compared with the control group.

endometrium of adenomyosis mice had a similar immunolocation as eutopic endometrium.

\section{Western blot analysis of NGF- $\beta$, proNGF and its receptors in the uterus}

The protein levels of NGF (13 kDa) and its precursors (proNGF, $27 \mathrm{kDa})$, p75NTR $(75 \mathrm{kDa})$ and trkA (145 kDa), in the uteri of adenomyosis and control mice were detected by western bolts (Figure 3). NGF, pro NGF, p75NTR and trkA levels increased in the uteri of adenomyosis mice as age increased $(190 \pm 5 \mathrm{~d}$ and $240 \pm 5 \mathrm{~d}, \mathrm{P}<0.05$, compared with $90 \pm 5 \mathrm{~d}$ ) and remained unchanged in controls. The expressions of NGF, its precursors and receptors of adenomyosis mice were higher than those in controls in the $190 \pm 5$ and $240 \pm 5 \mathrm{~d}$ age groups $(\mathrm{P}<0.05)$.

\section{Gene expression of trkA and p75NTR in the DRG}

The mRNA expressions of Ntrk1 (gene of trkA) and $N g f r$ (gene of p75NTR) in DRG of adenomyosis and control ICR mice in the different age groups were examined by real time RT-PCR. Ntrk1 levels were significantly increased in adenomyosis mice compared with those in controls $(190 \pm 5 \mathrm{~d}$ and $240 \pm 5 \mathrm{~d}, \mathrm{P}<0.05)$. Ntrk1 levels increased as age increased in adenomyosis mice $(190 \pm 5 \mathrm{~d}$ and $240 \pm 5 \mathrm{~d}, \mathrm{P}<0.05$, compared with $90 \pm 5 \mathrm{~d}$ ). The mRNA levels of $N g f r$ were not different between adenomyosis and control mice and remained stable as age increased (Figure 4).

\section{Discussion}

In this study, we investigated the expression of NGF and its receptors (p75NTR and trkA) in the uterus and DRG of mice with adenomyosis. A mouse model with progressively worsening adenomyosis was generated to study the relationship between the expression of NGF and the severity of adenomyosis. We showed that NGF$\beta, \mathrm{p} 75 \mathrm{NTR}$ and trkA protein levels in uteri and trkA mRNA levels in DRG were higher than those in controls, while they gradually increased as adenomyosis worsened.
We used tamoxifen administration to create the adenomyosis mouse model. The precise mechanism for this mouse model has not been fully clarified. It is proposed that paracrine signaling prevents differentiation of uterine myocytes in the mesenchyme, and over a period of time this may permit downgrowth of the endometrium into the myometrium [16]. In previous studies, the area and depth of the ectopic endometrium in uteri of an adenomyosis mouse model constantly increased as age increased $[17,31]$. In the present study, we showed a progressively infiltrated endometrium (Figure 1) and increased uterine weight (Table 1) in adenomyosis mice. In mice administered with tamoxifen, initially their uteri were lighter, which might have been the result of depauperate mesenchyme [17] and then they became heavier, which might have been because of ectopic endometrium proliferation [2], compared with controls. We chose four progressive age groups to represent four stages of adenomyosis.

In the present study, immunoreactivity of NGF- $\beta$ was predominantly detected in the luminal and glandular epithelial cells, and stromal cells of the endometrium. We observed p75NTR mainly in stromal cells of the endometrium and trkA in nerve fibers as well as in luminal and glandular epithelial cells. The immunolocation of NGF- $\beta$, p75NTR and trkA in the ectopic endometrium was similar to eutopic endometrium in adenomyosis mice. Our finding of NGF's location is consistent with previous studies [32]. However, beside nerve fibers $[12,15]$, we also found p75NTR and trkA immunostaining in endometrial cells. The expression of NGF and its receptors in functional cells of the uterus suggests a local effect, except for the well known effect in the nervous system.

We examined the abnormal increase of NGF and its receptors in uteri of adenomyosis mice by western blot. NGF- $\beta$, p75NTR and trkA protein levels in uteri gradually increased while age increased in adenomyosis mice, but they remained unchanged in control mice. In adenomyosis mice, as age increases, the disease progresses $[17,31]$. Therefore, NGF can be used as an indicator for the severity of adenomyosis. As a multi-functional cytokine and growth factor, over expression of NGF might exert an effect in multiple different ways. NGF is crucial for the development of sympathetic and small fiber sensory neurons that serve as nociceptors [6,7]. For adenomyosis, which also has an increased density of nerve fibers in the uterus of symptomatic patients [33], NGF might have the contribution to this abnormal innervation. NGF plays a crucial role in the generation of pain and hyperalgesia in several acute and chronic pain states $[34,35]$. NGF increases the excitability of primary afferents by altering ion channels or neurotransmitter production [36-38]. As a chemoattractant for granulocytes 

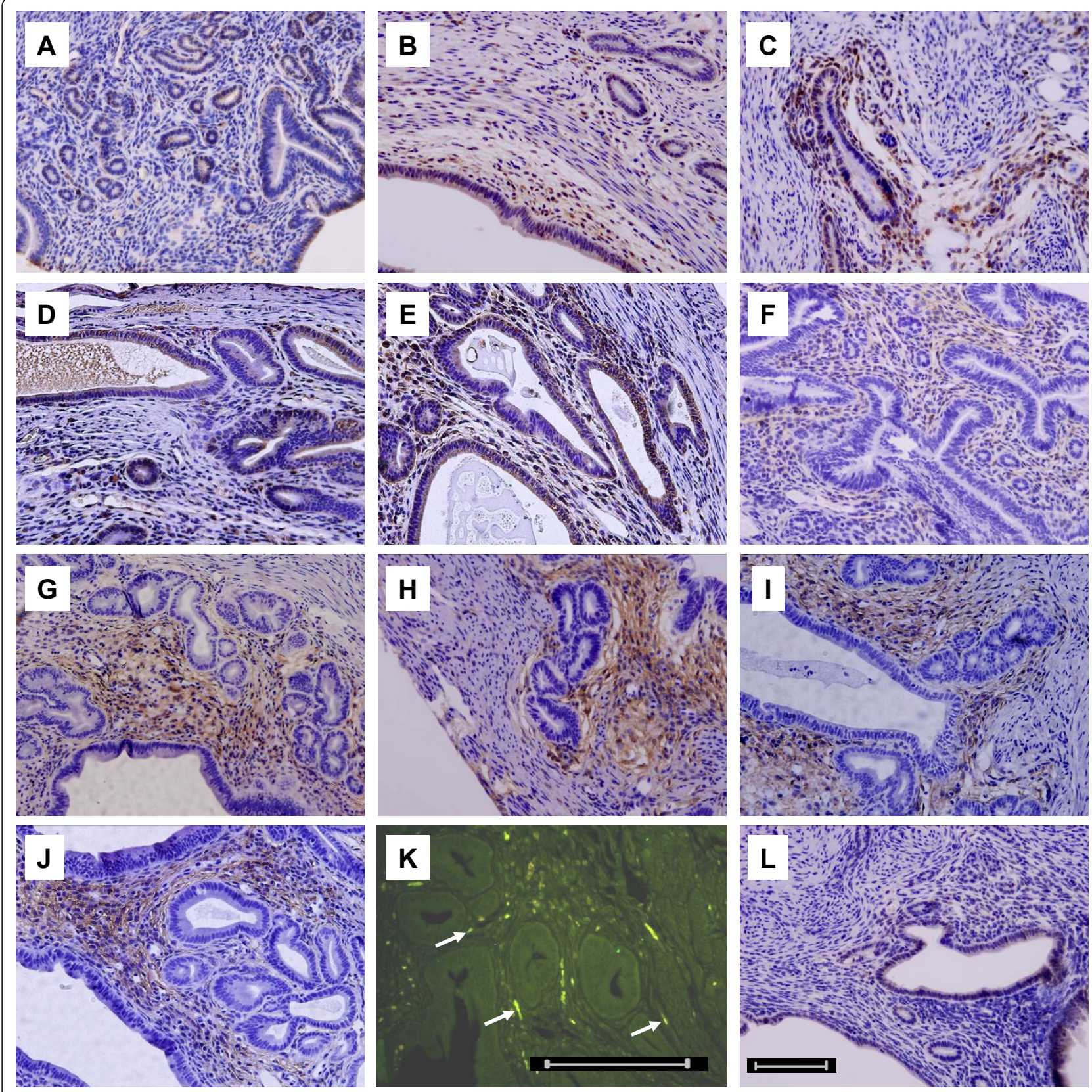

Figure 2 Immunostaining of NGF- $\beta$, p75NTR and trkA in uteri of ICR mice with adenomyosis or not. A: Uterus of $140 \pm 5 d$ control ICR mice stained for NGF- $\beta$. B-E: Immnostaining of NGF- $\beta$ in uterus of $90 \pm 5 d, 140 \pm 5 d, 190 \pm 5 d$ and $240 \pm 5 d$ ICR mice with adenomyosis, respectively. F: Uterus of $140 \pm 5 \mathrm{~d}$ control ICR mice stained for p75NTR. G-J: Immnostaining of p75NTR in uterus of $90 \pm 5 \mathrm{~d}, 140 \pm 5 \mathrm{~d}, 190 \pm 5$ $\mathrm{d}$ and $240 \pm 5 \mathrm{~d}$ ICR mice with adenomyosis, respectively. K-L: trkA immnoreactivity was detected in nerve fibers (K; arrows, nerve fibers), luminal and glandular epithelial cells of endometrium $(L)$ in uterus of adenomyosis ICR mice aged $140 \pm 5 \mathrm{~d}$. (Bar $=100 \mu \mathrm{m})$.

and mast cells, NGF strengthens immunoreactions and stimulates the degranulation of mast cells, which helps the release of pain-producing substances [39]. Therefore we speculate that this ever-increasing NGF effect in severe adenomyosis might contribute to the aggressive pain accompanied by this disease. NGF also has a relationship with uterine weight and participates in stress- triggered and substance P-mediated abortion $[28,30]$. These findings might be important for studies on adenomyosis-related hysterauxesis and spontaneous abortion.

The antibody we used for NGF- $\beta$ (13 kD) can bind to proNGF $(27 \mathrm{kD})$. As a precursor, proNGF reflected the reserve of mature NGF- $\beta$ [40]. Pro-NGF can bind 


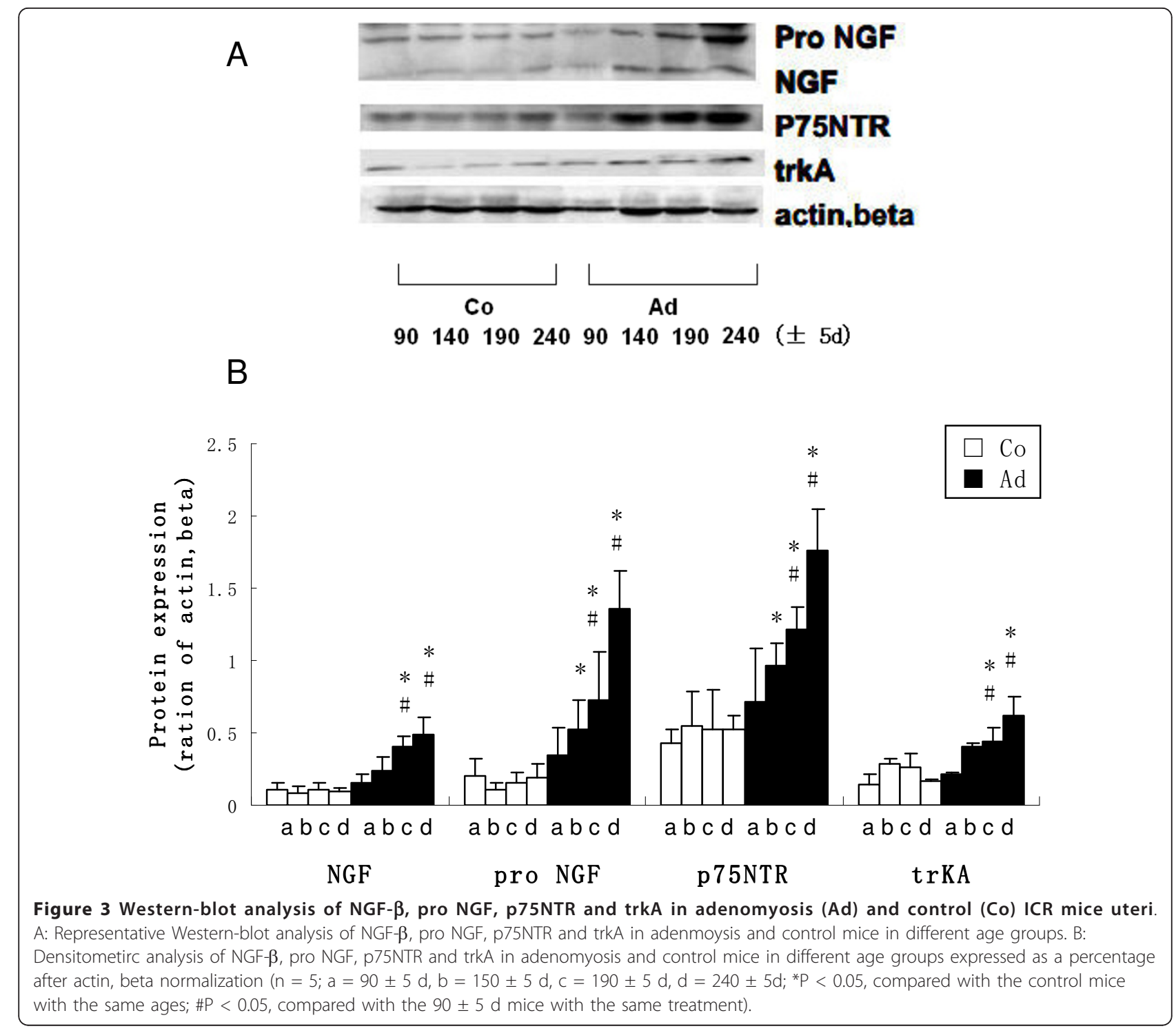

p75NTR with a high affinity and activate trkA, too $[40,41]$. In peripheral inflammation, pro-NGF is upregulated and it plays a crucial role in inflammatory hypersensitivity [40]. Our findings regarding the increase of proNGF suggest that there is an abundant NGF- $\beta$ store and that is has a biological effect on hypersensitivity in inflammation.

We observed that p75NTR was strongly expressed in endometrial stromal cells and weakly expressed in DRG, while trkA was strongly expressed in uterine nerve fibers and DRG but it was poorly expressed in luminal and glandular epithelial cells. These findings suggest that the stronger expression of p75NTR in the endometrium enables NGF to have a local effect on stromal cells of the uterus, while trkA might enable NGF to affect the peripheral and central nervous system. NGF could be taken up by nerve terminals and transferred to the central nervous system to exert its effect. We detected mRNA levels of NGF receptors but not NGF itself in DRG, which is not unexpected because NGF is not synthesized in this tissue [6].

The reason for the increase in NGF and its receptors in adenomyosis mice is unclear. The level of NGF- $\beta$ and its receptors was mostly normal in tamoxifen administered mice at the ages of $90 \pm 5 \mathrm{~d}$ and $140 \pm 5 \mathrm{~d}$ for which ectopic endometrium was observed in the myometrium. This suggests that the abnormal expression of NGF- $\beta$ is only an association but not the cause of adenomyosis. Estrogen promotes the expression of NGF in endometrium [42]. Adenomyosis has been shown to be an estrogen-dependent disease that has abnormal local estrogen production in the uterus $[43,44]$. Therefore, 

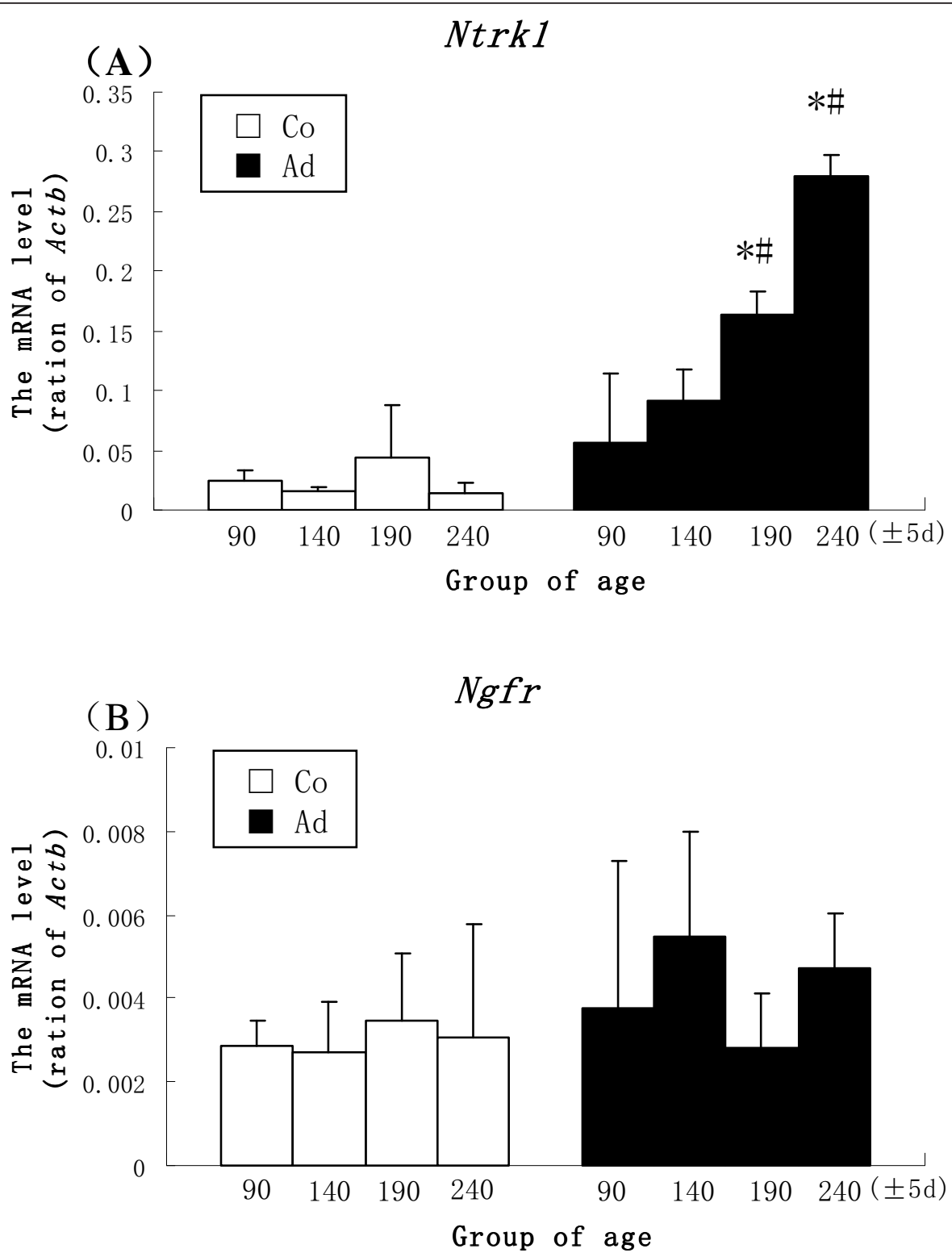

Figure 4 mRNA expression of Ntrk1 and Ngfr in DRGs of adenomyosis (Ad) and control (Co) mice. A: the mRNA level of Ntrk1 in DRGs of adenomyosis and control mice for different age groups. B: the Ngfr level in DRGs of adenomyosis and control mice for different age groups. (n $=4$; ${ }^{P}<0.05$, compared with the control mice with the same ages; $\# P<0.05$, compared with the $90 \pm 5 \mathrm{~d}$ mice with the same treatment).

abnormal local estrogen levels might be responsible for the increase in NGF. It has also been reported that NGF is associated with a variety of autoimmune and inflammatory diseases (e.g. allergic diseases and asthma $[45,46]$, and intestinal mucosa inflammation [47]) in which elevated NGF levels correlate well with the severity of the diseases. It is well known that adenomyosis is accompanied by various autoimmune phenomena in humans. For example, patients with adenomyosis have an increased number of macrophages, gamma delta $\mathrm{T}$ cells in ectopic and eutopic endometrium, and elevated preinflammatory factors and cytokines (e.g.
TNF- $\alpha$, IL-10, and IL-18) in the uterus and peritoneal fluid $[29,48,49]$. The augmentation of NGF might be the result of inflammatory status and then mediate and/or regulate the immune response. Therefore, we speculate that with the infiltration and growth of ectopic endometrium, uterine inflammation and local estrogen synthesis are increased, which could promote NGF synthesis. NGF might then participate in neural plasticity, local inflammation and production of pain. Therefore, it is possible that NGF might be one of the important factors that participate in the pathological mechanism of adenomyosis. In addition, it is worth mentioning that western 
blot and RT-PCR were performed from the whole uterus in this study. However, endometrial glandular, stromal, and myometrial components may differ in the expression of NGF and its receptors as the data of immunohistochemistry showed. So the increase of endometrial glandular and stromal in adenomyosis might affect the expression of NGF and receptors, too.

In the present study, we evaluated the expression of NGF, p75NTR and trkA in uteri and DRG of adenomyosis mice. The protein levels of NGF and its receptors in uteri and trkA mRNA levels in DRG were higher in adenomyosis mice compared with those in controls, and these levels increased with the severity of disease. Recently, a novel class of pain drugs that are based on antagonism of NGF have been investigated with a promising outcome [50]. Our results also suggest the possibility of anti-NGF therapy for curing adenomyosis pain; however, further study is required to determine this issue.

\section{Acknowledgements}

This study was supported by research funding for Shanghai medical intensive subjects construction (Obstetrics and Gynaecology).

\section{Author details}

'Department of Gynaecology, Obstetrics and Gynaecology Hospital, Fudan University, Shanghai, 200011, PR China. ²Reproductive medicine center, Ruijin Hospital, Shanghai Jiaotong University School of Medicine, Shanghai, 200025, PR China.

\section{Authors' contributions}

YL has participated in study design, execution, analysis, manuscript drafting. SFZ has participated in study design, manuscript drafting and critical discussion. SEZ has participated in execution, analysis and critical discussion, XX has participated in execution and critical discussion, LB has participated in execution and analysis. All authors read and approved the final manuscript.

\section{Competing interests}

The authors declare that they have no competing interests.

Received: 15 October 2010 Accepted: 8 March 2011

Published: 8 March 2011

\section{References}

1. Lee NC, Dicker RC, Rubin GL, Ory HW: Confirmation of the preoperative diagnoses for hysterectomy. Am J Obstet Gynecol 1984, 150:283-287.

2. Ferenczy A: Pathophysiology of adenomyosis. Hum Reprod Update 1998, 4:312-322

3. Khan KN, Kitajima M, Hiraki K, Fujishita A, Sekine I, Ishimaru T, Masuzaki H: Changes in tissue inflammation, angiogenesis and apoptosis in endometriosis, adenomyosis and uterine myoma after $\mathrm{GnRH}$ agonist therapy. Hum Reprod 2010, 25:642-53.

4. Leyendecker G, Wildt L, Mall G: The pathophysiology of endometriosis and adenomyosis: tissue injury and repair. Arch Gynecol Obstet 2009, 280:529-538.

5. Liu H, Lang J, Wang X, Wu S: Comparative proteomic analysis of human adenomyosis using two-dimensional gel electrophoresis and mass spectrometry. Fertil Steril 2008, 89:1625-1631.

6. Levi-Montalcini R: The nerve growth factor 35 years later. Science 1987, 237:1154-1162.

7. Snider WD: Functions of the neurotrophins during nervous system development: what the knockouts are teaching us. Cell 1994, 77:627-638.
8. Li Y, Zhang $S$, Xian X, Zou S: Adenomyosis uterine innervation in mice correlates to nerve growth factor expression, inflammation, and vascularization. Neural Regen Res 2010, 5:15-20.

9. Evans S, Moalem-Taylor G, Tracey DJ: Pain and endometriosis. Pain 2007, 132:S22-25.

10. Tokushige N, Markham R, Russell P, Fraser IS: High density of small nerve fibres in the functional layer of the endometrium in women with endometriosis. Hum Reprod 2006, 21:782-787.

11. Mechsner S, Schwarz J, Thode J, Loddenkemper C, Salomon DS, Ebert AD: Growth- associated protein 43-positive sensory nerve fibers accompanied by immature vessels are located in or near peritoneal endometriotic lesions. Fertil Steril 2007, 88:581-587.

12. Zhang G, Dmitrieva N, Liu Y, McGinty KA, Berkley KJ: Endometriosis as a neurovascular condition: estrous variation in innervation, vascularization, and growth factor content of ectopic endometrial cyst in the rat. Am J Physiol Regul Integr Comp Physiol 2008, 294:R162-171.

13. Anaf $V$, Simon P, El Nakadi I, Fayt I, Simonart T, Buxant F, Noel JC: Hyperalgesia, nerve infiltration and nerve growth factor expression in deep adenomyotic nodules, peritoneal and ovarian endometriosis. Hum Reprod 2002, 17:1895-1900

14. Chalar C, Richeri A, Viettro L, Chavez-Genaro R, Bianchimano P, Marmol NM, Crutcher K, Burnstock G, Cowen T, Brauer MM: Plasticity in developing rat uterine sensory nerves: the role of NGF and TrkA. Cell Tissue Res 2003, 314:191-205

15. Tokushige N, Markham R, Russell P, Fraser IS: Nerve fibres in peritoneal endometriosis. Hum Reprod 2006, 21:3001-3007.

16. Green AR, Edwards RE, Greaves P, White IN: Comparison of the effect of oestradiol, tamoxifen and raloxifene on nerve growth factor-alpha expression in specific neonatal mouse uterine cell types using laser capture microdissection. J Mol Endocrinol 2003, 30:1-11.

17. Greaves P: Experimental adenomyosis. Best Pract Res Cl Ob 2006, 20:503-510.

18. Crowley C, Spencer SD, Nishimura MC, Chen KS, Pitts-Meek S, Armanini MP, Ling $L H$, McMahon SB, Shelton DL, Levinson AD: Mice lacking nerve growth factor display perinatal loss of sensory and sympathetic neurons yet develop basal forebrain cholinergic neurons. Cell 1994, 76:1001-1011.

19. McMahon SB: NGF as a mediator of inflammatory pain. Philos Trans $R$ Soc Lond B Biol Sci 1996, 351:431-440.

20. Davis BM, Lewin GR, Mendell LM, Jones ME, Albers KM: Altered expression of nerve growth factor in the skin of transgenic mice leads to changes in response to mechanical stimuli. Neuroscience 1993, 56:789-792.

21. Petty BG, Cornblath DR, Adornato BT, Chaudhry v, Flexner C, Wachsman M, Sinicropi $D$, Burton LE, Peroutka SJ: The effect of systemically administered recombinant human nerve growth factor in healthy human subjects. Ann Neurol 1994, 36:244-246.

22. Schaible HG, Del Rosso A, Matucci-Cerinic M: Neurogenic aspects of inflammation. Rheum Dis Clin North Am 2005, 31:77-101.

23. Freund-Michel $\mathrm{V}$, Frossard $\mathrm{N}$ : The nerve growth factor and its receptors in airway inflammatory diseases. Pharmacol Ther 2008, 117:52-76.

24. Dines KC, Powell HC: Mast cell interactions with the nervous systerm: Relationship to mechanisms of disease. J Neuropathol Exp Neurol 1997, 56:627-640.

25. Rende M, Brizi E, Conner J, Treves S, Censier K, Provenzano C, Taglialatela G, Sanna PP, Donato R: Nerve growth factor (NGF) influences differentiation and proliferation of myogenic cells in vitro via TrKA. Int J Dev Neurosci 2000, 18:869-885.

26. Schnegelsberg B, Sun TT, Cain G, Bhattacharya A, Nunn PA, Ford AP Vizzard MA, Cockayne DA: Overexpression of NGF in mouse urothelium leads to neuronal hyperinnervation, pelvic sensitivity, and changes in urinary bladder function. Am J Physiol Regul Integr Comp Physio 2010, 298: R534-47.

27. Qi H, Li DQ, Shine HD, Chen Z, Yoon KC, Jones DB, Pflugfelder SC: Nerve growth factor and its receptor TrkA serve as potential markers for human corneal epithelial progenitor cells. Exp Eye Res 2008, 86:34-40.

28. Tometten M, Klapp BF, Joachim R, Fest S, Zenclussen AC, Peters EM, Hertwlg K, Arck PC: Nerve growth factor and its functional receptor TrkA are up-regulated in murine decidual tissue of stress-triggered and substance P-mediated abortion. Am J Reprod Immunol 2004, 51:86-93.

29. Ota $\mathrm{H}$, Igarashi $\mathrm{S}$, Hatazawa J, Tanaka $\mathrm{T}$ : Is adenomyosis an immune disease? Hum Reprod Update 1998, 4:360-367. 
30. Shi Z, Arai K, Jin W, Weng Q, Watanabe G, Suzuki AK, Taya K: Expression of nerve growth factor and its receptors NTRK1 and TNFRSF1B is regulated by estrogen and progesterone in the uteri of Golden Hamsters. Biol Reprod 2006, 74:850-856.

31. Li Y, Zhang S, Xia X, Zou S: Establishment of an ICR mouse modle of adenomyosis by oral administration of tamoxifen. Acta Lab Or Aatorium Animalis Scientia Sinica 2009, 17:346-350.

32. Bjorling DE, Beckman M, Clayton MK, Wang ZY: Modulation of nerve growth factor in peripheral organs by estrogen and progesterone. Neuroscience 2002, 110:155-167.

33. Zhang $X, L u B$, Huang $X, X u H$, Zhou $C$, Lin J: Innervation of endometrium and myometrium in women with painful adenomyosis and uterine fibroids. Fertil Steril 2010, 94:730-737.

34. Mendell LM, Albers KM, Davis BM: Neurotrophins, nociceptors, and pain. Microsc Res Tech 1999, 45:252-261.

35. Watson JJ, Allen SJ, Dawbarn D: Targeting nerve growth factor in pain what is the therapeutic potential. BioDrugs 2008, 22:349-359.

36. Mamet J, Baron A, Lazdunski M, Voilley N: Proinflammatory mediators, stimulators of sensory neuron excitability via the expression of acidsensing ion channels. J Neurosci 2002, 22:10662-10670.

37. Xue Q, Jong B, Chen T, Schumacher MA: Transcription of rat TRPV1 utilizes a dual promoter system that is positively regulated by nerve growth factor. J Neurochem 2007, 101:212-222.

38. Bielefeldt K, Ozaki N, Gebhart GF: Role of nerve growth factor in modulation of gastric afferent neurons in the rat. Am J Physiol Gastrointest Liver Physiol 2003, 284:G499-507.

39. Lewin GR, Rueff A, Mendell LM: Peripheral and central mechanism of NGF-induced hyperalgesia. Eur J Neurosci 1994, 6:1903-1912.

40. Boutilier J, Ceni C, Pagdala PC, Forgie A, Neet KE, Barker P: Proneurotrophins require endocytosis and intracellular proteolysis to induce TrkA activation. J Biol Chem 2008, 283:12709-12716.

41. Watanabe T, Toshinori Ito, Inoue G, Ohtori S, Kitajo K, Doya H, Takahashi K Yamashita T: The p75 Receptor is associated with inflammatory thermal hypersensitivity. J Neurosci Res 2008, 86:3566-3574.

42. Pedchenko T, Hasan W, Smith PG: Oestrogen regulates sympathetic neurite outgrowth by modulating brain derived neurotrophic factor synthesis and release by the rodent uterus. Eur J Neurosci 2003, 18:2760-2768.

43. Ishihara H, Kitawaki J, Kado N, Koshiba H, Fushiki S, Honjo H: Gonadotropin- releasing hormone agonist and danazol normalize aromatase cytochrome P450 expression in eutopic endometrium from women with endometriosis, adenomyosis, or leiomyomas. Fertil Steril 2003, 79:735-742.

44. Kitawaki J: Adenomyosis: the pathophysiology of an oestrogendependent disease. Best Pract Res Clin Obstet Gynaecol 2006, 20:493-502.

45. Bonini S, Lambiase A, Lapucci G, Properzi F, Bresciani M, Bracci Laudiero ML, Mancini MJ, Procoli A, Micera A, Sacerdoti G: Nerve growth factor and asthma. Allergy 2002, 57(Suppl 72):13-15.

46. Abram M, Wegmann M, Fokuhl V, Sonar S, Luger EO, Kerzel S, Radbruch A, Renz H, Zemlin M: Never growth factor and neurotrophin-3 mediate survival of pulmonary plasma cells during the allergic airway inflammation. J Immunol 2009, 182:4705-4712.

47. Agro A, Stanisz AM: Inhibition of murine intestinal inflammation by antisubstance P antibody. Reg Immunol 1993, 5:120-126.

48. Huang HY, Yu HT, Chan SH, Lee CL, Wang HS, Soong YK: Eutopic endometrial interleukin-18 system mRNA and protein expression at the level of endometrial myometrial interface in adenomyosis patients. Fertil Steril 2010, 94:33-39.

49. Wang F, Li H, Yang Z, Du X, Cui M, Wens Z: Expression of interleukin-10 in patient with adenomyosis. Fertil Steril 2009, 91:1681-1685.

50. Hefti FF, Rosenthal A, Walicke PA, Wyatt s, Vergara G, Shelton DL, Davies AM: Novel class of pain drugs based on antagonism of NGF. Trends Pharmacol Sci 2006, 27:85-91.

doi:10.1186/1477-7827-9-30

Cite this article as: Li et al:: Accumulation of nerve growth factor and its receptors in the uterus and dorsal root ganglia in a mouse model of adenomyosis. Reproductive Biology and Endocrinology 2011 9:30.

\section{Submit your next manuscript to BioMed Central and take full advantage of:}

- Convenient online submission

- Thorough peer review

- No space constraints or color figure charges

- Immediate publication on acceptance

- Inclusion in PubMed, CAS, Scopus and Google Scholar

- Research which is freely available for redistribution 